\title{
Reformed Development: How Edmonton Can Benefit From Globalization Through Improved Development Strategies
}

\author{
By Mack Nugent
}

\begin{abstract}
Achieving economic success in a globalized world is a complex task for cities. One of the most important challenges cities need to address to reach prosperity is how they plan their development. Creating a socially, and economically attractive environment can help cities prosper. This essay explores the development impediments that Edmonton has experienced in the last few essays. Specifically Edmonton's focus on suburbanization has put Edmonton at a competitive disadvantage internationally. However, with strategies explored, Edmonton can drastically improve its quality of life.
\end{abstract}

Contemporary globalization presents Edmonton, Alberta with an opportunity to thrive culturally and economically. However, Edmonton's developmental history has placed the city at a disadvantage to maximize its global appeal and therefore, its economic potential. Within the last twenty-five years, urban development has primarily been influenced by inefficient city planning, such as expansive suburbanization and underdevelopment of mass transit. Resultantly, Edmonton's second-class urban environment is culturally unattractive to highly educated immigrants, young professionals, and big businesses, which impairs the city's economic potential. However, the modern recognition of the importance of efficient urban design may heighten the cultural and economic benefits of globalization, within Alberta's capital.

Edmonton's housing and retail development is notoriously low density originating from the baby boomer paradigm. During this transformative era, automobiles, single-family housing and suburbs became the foundations of North American cultural development. ${ }^{1}$ At the same time, Edmonton also adopted the suburbanization movement. Within the last twenty-five years, suburbanization has been perpetuated through the construction of peripheral suburban neighbourhoods, sizable shopping malls, and open-air retail development centers, such as South Edmonton Common. Aside from residents in centrally located neighbourhoods, Edmontonians are now largely dependent on vehicular transportation. As a result of continuous suburbanization, Edmonton is now characterized by vast parking lots, empty sidewalks, and considerable driving distances.

While suburban growth flourished, downtown Edmonton experienced negligible residential development, as suburban trends focused development away from the downtown core. Distantly located suburban residences limited economic prosperity downtown, due to inaccessibility and inconvenience for suburbanites. Proximally situated necessities, such as clothing and grocery stores, discouraged suburbanites from contributing to the downtown economic environment. Consequently, suburban expansion detracted from downtown residential development despite an increase in commercial development. ${ }^{2}$

\footnotetext{
1 Doug, Owram. "Safe in the Hands of Mother Suburbia: Home and Community, 1950-1965." University of Toronto Press, 1997. 58.

2 David Lay. The New Middle Class in Canadian Cities. Oxford University Press. December 1996. 18
} 
Edmonton's suburbanization issues have been amplified by inefficient mass transit. Consistent with Edmonton's sprawling growth patterns, a plethora of roads were developed to accommodate suburban drivers, outpacing mass transit development. Additionally, although Edmonton was the first city in North America to construct an LRT line, expansion slowed dramatically. The delay in LRT expansion is largely a result of fiscally conservative councilors who were unable to realize the economic benefit of transit. For example, former city councilor Terry Nugent argued for decades "it would be cheaper to drive people around in limousines than to expand the LRT"3*. As a result, between 1978 and 2009 the Edmonton LRT has only expanded by an average of 250 meters a year, despite a population increase greater than 300 $000 .{ }^{4}$ Currently, limited transit restricts public access to the city centre and subsequently reduces the economic viability of centrally located businesses. Moreover, an absence of efficient public transportation creates difficulties for urban dwellers that often prefer to live without a vehicle, and further reduces the desire to live downtown. Insufficient transit service to downtown has exacerbated the consequences of suburbanization for current and prospective businesses and residents.

Suburbanization has devalued the cultural appeal and limited the lifestyle possibilities for Edmonton's citizens. Suburban influence has also oriented the city to prioritize the needs of suburban families. Quiet, secluded streets, which may be ideal for young families, provide minimal excitement for young people, urban enthusiasts, and tourists. Additionally, Edmonton lacks the lifestyle preferred by young professionals, existent in competing cities. Many young professionals prefer to live in vibrant areas with amenities within walking distance of their homes and places of work. ${ }^{5}$ These urban dwellers are commonly referred to as Yuppies or young urban professionals. ${ }^{6}$ Suburban areas are particularly unattractive to yuppies, as they are unable to provide the desired lifestyle. As businesses actively seek to relocate to cities that provide a high quality lifestyle for their workers, Edmonton would benefit from an increase in neighbourhoods that provided more amenities. ${ }^{7}$

While there are areas in Edmonton capable of accommodating the preferred lifestyle of yuppies, such as the downtown core and Oliver, these neighbourhoods are comparatively smaller and contain fewer amenities than neighbourhoods in other large Canadian cities. For example, the population of downtown Edmonton is barely over eleven thousand people, while the population of downtown Vancouver is approximately 80000 people. ${ }^{89}$ Downtown Vancouver offers compelling amenities for its residents, which are unavailable in Edmonton's downtown because of its limited population. Therefore, Edmonton is at a disadvantage at attracting young

\footnotetext{
3 *While this is not recorded in writing, as his Grandson, I can attest to Mr. Nugent passionately reiterating this line.

4 "History of the ETS." City of Edmonton. http://www.edmonton.ca/transportation/ets/history-of-ets.aspx. Accessed February 2, 2010.

5 Mark, Abrahamson. Global Cities. Oxford University Press, New York. 2004. 33.

6 Idem.

7 Tim Hutton. "Location Change in Canadian Cities: Location Dynamics of Employment". Canadian Cities in Transition. Edited by Trudi Bunting, Pierre Filion, and Ryan Walker, 110-130. Canada: Oxford University Press, $2010,122$.

8 “2009 Municipal Census". The City of Edmonton, 2009. www.edmonton.ca, accessed on January 312010.

9 Linda, Baker. "Vancouver's downtown may become victim of its urban housing success". International Harold Tribune, January $17^{\text {th }} 2007$. New York Times Online. http://www.nytimes.com, Accessed on January 31, 2010.
} 
professionals in light of more attractive competition. For example, research by the Conference Board of Canada demonstrated that Edmonton is the twelfth most desirable city in Canada for young professionals. ${ }^{10}$ Additional urban neighbourhoods and amenities will be required if Edmonton is to increase its appeal to young urban professionals.

Edmonton's economy is disadvantaged by the city's poor cultural appeal to young professionals. Although Edmonton boasts one of Canada's most prestigious post-secondary institutions, the University of Alberta, many graduates relocate, as other cities provide more attractive, high-end job markets. Consequently, the relatively small number of professionals living and working in Edmonton hinder the city's economic potential. Furthermore, Edmonton has a smaller market for higher-level employment because it has significantly fewer corporate head offices than other major Canadian cities ${ }^{11}$. Plausibly, companies contemplating relocation are less inclined to consider Edmonton because it does not have the employee appeal of other cities. Therefore, Edmonton loses the potential economic benefit that it could receive if it was capable of attracting sizable numbers of young professionals.

Although economic globalization has attracted a significant number of immigrants, Edmonton does not entice the most educated immigrants. As one of Canada's six largest cities, Edmonton attracts the least educated immigrants and the highest proportion of immigrants who work in the lowest paying jobs. ${ }^{12}$ Although the immigrants who arrive are integral to city growth, they provide less of an economic benefit than do the more affluent immigrants. Careers requiring higher levels of education equate to higher salaries and therefore, a larger economic benefit to the city. However, Edmonton is not achieving its economic potential, because it is unable to attract foreign professionals. Edmonton will need to redirect its approach in order to benefit from the potential contribution from foreign professionals.

Recently, Edmonton has acknowledged the value of national and international allure. The last several years have largely consisted of urban renewal for downtown Edmonton. During this period, the population of downtown Edmonton has nearly doubled, due to an increase in downtown revitalization efforts. ${ }^{13}$ Growth has occurred from city led by the city. For example, between 1997 and 2010 roughly 4000 condo and apartment units were constructed in downtown area neighbourhoods with grants from the city. ${ }^{14}$ Furthermore, in recent years gentrification has been occurring in centrally located neighbourhoods. Gentrification refers to the process where an impoverished neighbourhood in a convenient area begins to improve its attractiveness due to efforts by the locals. As a result, the neighbourhood becomes more attractive and young professionals move into the neighbourhood, because the urban lifestyle of that it provides become more fashionable. ${ }^{15}$ While this process is occurring in some neighbourhoods, Edmonton remains in its infancy, in regards to development of attractive urban neighbourhoods.

\footnotetext{
10 "Edmonton Seventh Most Attractive For Newcomers." Edmonton Journal. January $14^{\text {th }} 2010$.

${ }^{11}$ Calgary Economic Development. "Calgary Head Office Fact Sheet." February 25, 2008

${ }^{12}$ Federation of Canadian Municipalities. . Quality of life in Canadian communities: immigration and diversity in Canadian cities and communities. Gibson Library Collections, (2009). Accessed January 31 2010, 20.

13 "2009 Municipal Census". The City of Edmonton. 2009. www.edmonton.ca, Accessed on January 312010

${ }^{14}$ Capital City Downtown Plan. The City of Edmonton August $9^{\text {th }}$ 2009. www.edmonton.ca, Accessed on January $312009,3$.

15 Abrahamson, Mark. Global Cities. Oxford University Press. New York 2004. 33.
} 
In recent years, Edmonton city council has began to realize the shortcomings of suburban oriented urban planning, and has pursued development with stronger urban foundations. With the arrival of mayor Stephen Mandel and a more progressive-minded council, the city is now pursuing downtown revitalization as well as significant expansions to the LRT system as well as the hopeful construction of three new LRT lines by $2017 .{ }^{16}$ However, due to a recent neglect of transit funding and abandonment of Edmonton's Expo 2017 bid by the Harper government, it is unrealistic that Edmonton can meet its ambitious transit goals. ${ }^{17}$ Many of the proposed changes are available in the city's "Capital City Downtown Plan," which is aims to significantly increase employment and population in downtown Edmonton. ${ }^{18}$ Moreover, recent emphasis has been placed on more bike lanes, creating another alternative to vehicular transportation. The city has also released a new plan to increase the number of people living downtown to twenty five thousand by the year 2029. ${ }^{19}$ However, the city encounters the problem of people not desiring to move downtown, unless there is sufficient development to entice them. Yet, development cannot occur without a demand for people to want to live downtown. Despite the setback, the city council seems to have shifted its interest to appealing urban development.

Edmonton has the opportunity to re-brand its reputation as a global city to improve its cultural and economic viability. The city boldly attempted bidding for hosting the 2017 World's Fair. If the bid were to have succeeded, Edmonton would have received billions of federal and provincial dollars that would be used to invest in such development as further LRT expansion and the creation of more urban style neighbourhoods. ${ }^{20}$ Additionally, the World's Fair would have provided Edmonton with international exposure and encourage further development and investment. Successful World's Fairs have transformed cities similar to Edmonton into globally recognized metropolises. For example, after Vancouver hosted the World's Fair in 1986, it has experienced nearly thirty years of constant urban growth and the share of residents living in compact communities rose from $46 \%$ to $62 \%$ in fifteen years. ${ }^{21}$ A stronger international image would improve Edmonton's economy and cultural appeal through increased visibility and accentuation of leading-edge developments. Although the federal government single handedly ended Edmonton's expo aspirations there are other urban development options the city can pursue.

The recent decision to close the City Center Airport provides Edmonton with an opportunity to curb suburbanization and create a transit oriented, urban neighbourhood, attractive to a wide array of people to a centrally located neighbourhood. In February 2011, the city

\footnotetext{
${ }^{16}$ Idem.

${ }^{17}$ Michelle, Thomson, “Expo's death sidetracks Edmonton's LRT expansion”. Edmonton Sun. November $26^{\text {th }}$ 2010. http://www.edmontonsun.com/news/edmonton/2010/11/25, np.

18 Capital City Downtown Plan. The City of Edmonton, August $9^{\text {th }} 2009$. www.edmonton.ca. Accessed on January 312010.29.

19 Ibid, 31.

${ }^{20}$ David, Martin. "Ottawa Pulls Support for Edmonton Expo Bid”. The National Post. November $22^{\text {nd }} 2010$. http:/www.nationalpost.com/news/canada/Ottawa+pulls+support +Edmonton+Expo/3867429/story.html, (accessed March 2, 2011), np.

21 "Greater Vancouver posts striking gains in compact growth, 15-year study shows." Sightline Institute. September $13^{\text {th }}$ 2002. http://www.sightline.org. Accessed February 3, 2010.
} 
released the proposals from the five companies who are opting to redesign the vacated airport land into a transit-oriented neighbourhood. ${ }^{22}$ All of the designs incorporate aspects of density, sustainability, walkability, and would appeal to those preferring an urban lifestyle. The new neighbourhood is being designed to accommodate more than thirty thousand residents, and could incorporate such concepts as canals, geothermal electricity generation, and central plazas. While this neighbourhood could take decades before it is fully constructed, it certainly represents an excellent development opportunity for the city. Furthermore, its proximity to downtown Edmonton will complement growth in the city's core.

Significant downtown investment would improve downtown appeal. In addition to a downtown arena, which would bring in thousands of people hockey games, concerts and other events, an entertainment district with residences, a casino, shopping and restaurants would encourage Edmontonians from around the city to visit downtown on a more frequent basis. This would promote additional residential development and possibly solve the development/demand first issue. The city would likely finance a moderate to significant amount of money for this development, which would create a desirable city and would attract young professionals and corporations. Consequently, the city would eventually earn a significant return on its investment from increased property tax revenue. Several American cities, including Columbus, Los Angeles, and Indianapolis have successfully revitalized their downtowns through arena developments. ${ }^{23}$ For example, ten years after an arena was constructed in downtown Columbus, property values around the arena increased by $267 \%$, and significantly increased revenues from property taxes. ${ }^{24}$ Edmonton has a similar opportunity to invest in its future urban allure.

Edmonton's development within the last quarter century has predominantly emphasized suburbanization over denser urban neighbourhoods, and neglected mass transit in favour of vehicular transportation. Subsequently, the city has not been able to accommodate the wide array of lifestyles that lead to global cultural appeal. Therefore, the economic contributions of affluent individuals, such as young professionals and educated immigrants, are negligible as a result of a substandard cultural appeal. Currently, the city is in the process of revitalizing its urban core, in an attempt to attract more highly educated immigrants, urban professionals and big businesses. With an increased focus placed on downtown cultural and economic development, Edmonton may emerge as Canada's next global city.

\footnotetext{
22 "City Centre Redevelopment”. The City of Edmonton. http://www.edmonton.ca/city_government /planning_development/edmonton-city-centre-airport-land redevelopment.aspx, (accessed March 2nd 2011), np.

${ }^{23}$ David, Staples. Could the Columbus Arena District be a model for Edmonton's Downtown. Edmonton Journal. December 1, 2009. Edmontonjournal.com. Accessed February 12010.

${ }^{24}$ Idem.
} 


\section{Bibliography}

“2009 Municipal Census”. The City of Edmonton. 2009. www.edmonton.ca, accessed on January 31 2010.

Abrahamson, Mark. Global Cities. New York: Oxford University Press, 2004. 31-33.

Baker, Linda. "Vancouver's downtown may become victim of its urban housing success". International Harold Tribune, January $17^{\text {th }} 2007$. New York Times Online. http://www.nytimes.com, Accessed on January 31, 2010.

"Calgary Head Office Fact Sheet". Calgary Economic Development February 252008.

Calgaryeconomicdevelopment.com, Accessed January 312010.

Capital City Downtown Plan. The City of Edmonton August $9^{\text {th }} 2009$. www.edmonton.ca, Accessed on January 312009.

"City Centre Redevelopment". The City of Edmonton. http://www.edmonton.ca/city_government /planning_development/edmonton-city-centre-airport-land redevelopment.aspx, (accessed March 2nd 2011).

"Edmonton Seventh Most Attractive For Newcomers". Edmonton Journal. January $14^{\text {th }} 2010$. Edmontonjournal.com. Accessed January 312010.

"Greater Vancouver posts striking gains in compact growth, 15-year study shows." Sightline Institute. September $13^{\text {th }}$ 2002. http://www.sightline.org. Accessed February 3, 2010.

"History of the ETS." City of Edmonton. http://www.edmonton.ca/transportation/ets/history-of-ets.aspx. Accessed February 2, 2010.

Hutton, Tim. "Location Change in Canadian Cities: Location Dynamics of Employment". Canadian Cities in Transition. Edited by Trudi Bunting, Pierre Filion, and Ryan Walker, 110-130. Canada: Oxford University Press, 2010.

Martin, David. "Ottawa Pulls Support for Edmonton Expo Bid". The National Post. November $22^{\text {nd }}$ 2010. http://www.nationalpost.com/news/canada/Ottawa+pulls+support

+Edmonton+Expo/3867429/story.html, (accessed March 2, 2011).

Quality of life in Canadian Communities: immigration and diversity in Canadian cities and communities. Federation of Canadian Municipalities. Gibson Library Collections, (2009): 11-25, http://ualweb.library.ualberta.ca, Accessed January 312010.

Staples, David. Could the Columbus Arena District be a model for Edmonton's Downtown. Edmonton Journal. December 1, 2009. Edmontonjournal.com. Accessed February 12010. 
“Stony Plain Road a go as LRT routes approved". CBC News. cbc.ca/Edmonton, Accessed on January 312010.

Thomson, Michelle. “Expo's death sidetracks Edmonton's LRT expansion”. Edmonton Sun. November $26^{\text {th }} 2010$. http://www.edmontonsun.com/news/edmonton/2010/11/25/16313766.html, (accessed February 19th 2011). 